ДВНЗ “Тернопільський державний медичний університет імені І. Я. Горбачевського МОЗ України”

\title{
РОЛЬ ЦИКЛОВОЇ МЕТОДИЧНОЇ КОМІСІЇ 3 ХІРУРГІЧНИХ ДИСЦИПЛІН В ОРГАНІЗАЦІЇ НАВЧАЛЬНОГО ПРОЦЕСУ ВИЩИХ НАВЧАЛЬНИХ ЗАКЛАДІВ
}

\author{
A. H. Shulhai, V. O. Shidlovskyi, L. Yu. Ivashchuk \\ I. Horbachevsky Ternopil State Medical University \\ THE ROLE OF CYCLE METHOD COMMISSION ON SURGICAL \\ DISCIPLINES IN THE ORGANIZATION OF EDUCATIONAL PROCESS AT \\ HIGHER EDUCATIONAL INSTITUTIONS
}

\begin{abstract}
Мета роботи - проаналізувати і оцінити роботу циклової методичної комісії із хірургічних дисциплін в організації навчального процесу вищих навчальних закладів.

Основна частина. Проведений аналіз 18-річної роботи циклової методичної комісії з хірургічних дисциплін ДВНЗ “Тернопільський державний медичний університет імені І. Я. Горбачевського МОЗ України”.

Діяльність методичної комісії із хірургічних дисциплін була спрямована на удосконалення організаційного та методичного забезпечення навчально-виховного процесу. Вона надавала рекомендації стосовно вдосконалення навчальних планів підготовки спеціалістів за відповідними напрямками та структурування змісту навчальних програм. Планування роботи методичної комісії здійснювали щорічно на основі рішень і рекомендацій ректорату, вченої ради університету, деканатів. План роботи складали на кожний навчальний рік у червні місяці. Після обговорення та схвалення методичною комісією план роботи затверджував ректор. Засідання методичної комісії проводили один раз на два місяці. При необхідності скликали оперативні позачергові засідання. У разі необхідності на засідання методичної комісії запрошували представників відповідних структурних підрозділів університету та окремих викладачів, які мали відношення до питань, що розглядали на методичній комісії. Рішення методичної комісії приймали відкритим голосуванням і вважали прийнятим тоді, коли за нього проголосувало більше половини присутніх на засіданні, доводили до відома працівників хірургічних кафедр університету впродовж 3-х днів. Однією $з$ особливостей роботи комісії була реалізація навчально-виховних цілей. Зміст цієї роботи полягав у вдосконаленні методичної майстерності викладачів, зміні авторитарно-дисциплінарної моделі навчання на особистісно-орієнтовану.

Висновок. Циклова методична комісія з хірургічних дисциплін повинна бути однією з ланок цілісної системи організації навчального процесу в медичному вищому навчальному закладі.
\end{abstract}

Ключові слова: вищий навчальний заклад; циклова методична комісія; хірургічні дисципліни.

The aim of the study - to review and evaluate the work of cycle method commission on surgical disciplines in the educational process at higher educational institutions.

The main body. The analysis of 18 years of work of cycle method commission on surgical disciplines at I. Horbachevsky Ternopil State Medical University was made. Methodical commission on surgical disciplines is aimed at improving organizational and method support of educational process. It provided recommendations for improving curriculum specialists in the relevant fields and structuring curriculum content. Planning of methodical commission is made annually on the basis of decisions and recommendations of the administration, academic council of the university dean. After plan discussion and approving by method commission it was approved by the rector. Method Commission Meeting is held once every two months. If necessary, extraordinary meetings are convened operational. At the meeting of Method Commission may invite representatives of relevant departments and individual teachers relating to matters dealt with in methodical commission. Commission Decision methodology adopted by open vote and can be considered as adopted one if it receives more than half votes of those present at the meeting, is put on notice of surgical departments of the University employees for up to 3 days. One feature of the commission is to implement educational purposes. The content of this work is to improve the method skills of teachers, changing authoritarian disciplinary training model focused on personality.

Conclusion. Cycle method commission on surgical disciplines should be one of the integral parts of the educational system at the medical university.

Key words: higher education institution; cycle method commission; surgical discipline.

(с) А. Г. Шульгай, В. О. Шідловський, Л. Ю. Іващук 
Вступ. Кардинальні зміни в соціально-політичному житті, які відбуваються в Україні, зумовлюють необхідність зміни підходів до системи виховання та навчання у вищих навчальних закладах, розробки та впровадження нових педагогічних технологій, які сприятимуть цілісному, гармонійному розвитку особистості студента, його самореалізації, грунтовному, духовно-креативному розумінню соціальної дійсності, зростання професійного рівня випускників $[1,4]$.

Розвиток української медичної освіти грунтується на введенні якісно нової методології організації навчального процесу за європейським зразком $[3,5]$. В основу концепції закладено європейські тенденції та національну стратегію. Важлива роль в організації навчального процесу відводиться цикловим методкомам, зокрема, із хірургічних дисциплін [6, 7].

Циклова комісія здійснює розробку та втілення в життя заходів, спрямованих на поліпшення якості на денній та заочній формах навчання, впровадження заходів щодо наукової організації навчального процесу, ознайомлення з методами і прийомами роботи викладачів, розробку методики викладання окремих навчальних дисциплін, проведення теоретичних, практичних занять [2, 9]. Вона також готує рекомендації щодо ефективного використання навчального обладнання, наочних посібників, нових педагогічних технологій у навчальному процесі, організації самостійної роботи студентів з вивчення окремих тем і розділів навчальної дисципліни. Завданнями $є$ і надання індивідуальної допомоги викладачам у плануванні роботи, оволодінні педагогічною майстерністю, організації та проведенні відкритих занять, занять гуртків у навчальних лабораторіях та кабінетах. Циклова комісія має право вносити пропозиції щодо змісту та обсягу діючих програм у зв'язку із специфікою медичної освіти, появою нової техніки, передового досвіду роботи та послідовності вивчення окремих тем суміжних і взаємозв'язаних навчальних дисциплін $[8,10]$.

Мета роботи - проаналізувати і оцінити роботу циклової методичної комісії із хірургічних дисциплін в організації навчального процесу вищих навчальних закладів.

Основна частина. Проведений аналіз 18-річної роботи циклової методичної комісії з хірургічних дисциплін ДВНЗ “Тернопільський державний медичний університет імені І. Я. Горбачевського МОЗ України”.

Діяльність циклової комісії із хірургічних дисциплін визначалася типовим положенням, на підставі якого навчальний заклад може розробляти положення про циклову комісію з урахуванням конкретних завдань, що стоять перед ним, і специфіки його роботи. Головна мета роботи комісії полягала в забезпеченні організації ефективної методичної роботи хірургічних кафедр та підрозділів університету, впровадження в навчальний процес сучасних технологій навчання.

Досягнення цієї мети циклова комісія здійснювала шляхом удосконалення змісту освіти та навчання, підвищення кваліфікаційного рівня викладачів, вивчення, узагальнення і розповсюдження передового педагогічного досвіду.

Головними завданнями методичної комісії із xiрургічних дисциплін були:

- визначення основних пріоритетів методичного забезпечення навчального процесу в університеті з урахуванням вітчизняного досвіду, національних традицій і тенденцій розвитку світових освітніх систем, узагальнення та впровадження прогресивних освітніх технологій;

- проведення методичної експертизи складових стандартів вищої освіти варіативної частини навчальних планів та програм на їх відповідність сучасним вимогам до професійної підготовки фахівців освітньо-кваліфікаційних рівнів, навчальнометодичної літератури, дидактичних засобів і програмних продуктів;

- методичний супровід здійснення навчання в умовах кредитно-трансферної системи організації навчального процесу;

- координація діяльності хірургічних навчальнометодичних підрозділів університету щодо підвищення якості та ефективності навчального процесу;

- вивчення вітчизняного та світового досвіду вищої медичної освіти і науки та впровадження його в навчальний процес;

- організація та проведення навчально-методичних конференцій професорсько-викладацького складу з актуальних проблем вищої медичної школи та підвищення педагогічної майстерності;

- обговорення нових навчальних планів підготовки фахівців, робочих навчальних планів та координація роботи щодо їх реалізації;

- обговорення та затвердження навчально-методичних матеріалів, підготовлених працівниками університету, і надання рекомендацій до видання та отримання відповідного грифа;

- координація роботи хірургічних опорних кафедр, затвердження їх звітів та планів роботи;

- контроль за якістю навчального процесу шляхом взаємних відвідувань лекцій та практичних занять $з$ подальшим їх обговоренням на ЦМК;

- впровадження в навчальний процес новітніх технологій та нових підходів до його організації. 
Діяльність методичної комісії із хірургічних дисциплін була спрямована на удосконалення організаційного та методичного забезпечення навчальновиховного процесу. Вона надавала рекомендації стосовно вдосконалення навчальних планів підготовки спеціалістів за відповідними напрямками та структурування змісту навчальних програм.

Планування роботи методичної комісії здійснювали щорічно на основі рішень і рекомендацій ректорату, вченої ради університету, деканатів і кафедр. План роботи складали на кожний навчальний рік у червні місяці. Після обговорення та схвалення методичною комісією план роботи затверджував ректор. Засідання методичної комісії проводили один раз на два місяці. При необхідності скликали оперативні позачергові засідання. На засідання методичної комісії, у разі необхідності, запрошували представників відповідних структурних підрозділів та окремих викладачів, які мали відношення до питань, що розглядали на методичній комісії.

Рішення методичної комісії приймали відкритим голосуванням. Рішення вважали прийнятим, якщо за нього проголосувало більше половини присутніх на засіданні методичної комісії, і доводили до відома працівників хірургічних кафедр університету протягом 3-х днів після проведення засідання.

Матеріали засідань методичної комісії оформляли протоколом за підписом голови та секретаря.

Організацію навчальної роботициклової комісії проводили з урахуванням можливостей вищого навчального закладу і його кафедр із застосуванням сучасних інформаційних технологій навчання. Систематично проводили аналіз успішності студентів, визначали причини неуспішності окремих студентів та намічали шляхи їх усунення. Для поліпшення навчання та успішності студентів комісія рекомендувала методики групового та індивідуального підходів. Це, зокрема, застосування у навчанні принципів дискусійності, проблемності, індивідуалізації та послідовності засвоєння освітніх програм. Разом з цим, систематично проводили аналіз змісту навчальних програм, вносили до них зміни, домагаючись логічності змісту тем дисципліни, що вивчаються, реалізації міжпредметних зв’язків і послідовності навчання. На основі аналізу підсумків поточного чи рубіжного контролів виявляли й аналізували причини низької успішності студентів та визначали методи і засоби її покращення.

Однією з особливостей роботи комісії була реалізація навчально-виховних цілей. Зміст цієї роботи полягав у вдосконаленні методичної майстерності викладачів, зміні авторитарно-дисциплінарної моделі навчання на особистісно орієнтовану.
Для надання викладачам методичної допомоги в удосконаленні професійної та ділової майстерності циклова комісія організовувала обговорення індивідуальних планів викладачів щодо підвищення теоретичного рівня та професійної кваліфікації; заслуховувала звіти про їх виконання. Викладачі хірургічних кафедр залучались до участі в підготовці, загальних по вищому навчальному закладу, методичних конференцій i семінарів по педагогіці у вищій школі, до рецензування методичних розробок, відеофільмів, навчальних посібників, програм та іншої методичної літератури.

Значну увагу циклова комісія приділяла вивченню й узагальненню передового педагогічного досвіду викладачів хірургічних дисциплін шляхом організації і проведення семінарів педагогічної майстерності.

Для вивчення ефективності роботи викладачів, встановлення рівня оптимальності нових форм i методів навчально-виховного процесу проводили педагогічні дослідження. Об’єктами цих досліджень були: педагогічна діяльність викладача, умови, що визначають цю діяльність, якість знань, умінь і навичок студентів.

Протягом 18 останніх років було проведено 82 засідання циклової методичної комісії з хірургічних дисциплін. Пріоритетними напрямками роботи комісії були питання та інновації в навчальному процесі, що дозволили наблизити українську вищу освіту до європейських стандартів. Серед них доцільно виділити наступне:

1. Методика єдиного дня. Відповідно до Концепції розвитку університету за результатами вивчення передового міжнародного досвіду в навчальний процес впроваджено ряд нових методик, таких, як: методика “Єдиного дня” навчання; Z-система освіти; матрикули практичних навичок; семестровий тестовий контроль; програма дистанційного контролю знань студентів “Moodle”; об’єктивноструктурований клінічний іспит; комунікативні навички. Методика “Єдиного дня”: при перебуванні на кафедрі впродовж 6-7-ми годин студенти мають можливість виконати значний обсяг практичної роботи, грунтовніше опанувати практичні навички, приділити більше часу самостійній курації хворих. Ця методика дозволила ефективно впровадити циклову систему навчання, а також потребувала створення на кафедрах тематичних навчальних кімнат, оснащення їх сучасним обладнанням (комп’ютери, відеотехніка, відеозв'язок), більш повноцінно забезпечити заняття тематичними хворими, ефективно використати матеріально-технічну базу кафедр.

2. Матрикули практичних навичок. Визначені практичні навички з дисципліни внесені у розроб- 
лені лінії практичних навичок, які розподілені по курсах і складені відповідно до галузевих стандартів освіти (освітньо-кваліфікаційної характеристики). Кожен студент зобов’язаний засвоїти практичні навички відповідно до зазначеного у матрикулі рівня. Передбачено п’ять рівнів засвоєння: 1) має відповідні знання (знає); 2) бачив, як дана навичка виконується (бачив); 3) вміє відтворити дану навичку на фантомі (вміє); 4) вміє продемонструвати практичну навичку в лабораторії, клініці на хворому під контролем викладача (вміє під контролем); 5) досконало оволодів практичною навичкою (вміє самостійно). В університеті створено всі умови для засвоєння і виконання практичних навичок студентами, як під час практичного заняття, так і в позааудиторний час.

3. Об'єктивний структурований клінічний іспит. Для забезпечення контролю засвоєння студентами практичних навичок на медичному та стоматологічному факультетах запроваджено об’єктивний структурований клінічний іспит (OCKI). Для ОСКІ використовуються практичні навички з третім, четвертим та п’ятим рівнями виконання, які містяться у матрикулах відповідних ліній, що сприяє більш ефективному засвоєнню їх студентами.

4. Єдиний комплексний тестовий іспит. 3 метою об’ єктивності оцінювання знань студентів під час складання іспитів запроваджено єдиний комплексний тестовий іспит. На іспит для студентів виносяться тестові завдання з усіх модулів всіх дисциплін, які вивчалися студентами впродовж осіннього або весняного семестру. Проведення іспиту здійснює створений загальноуніверситетський центр незалежного тестування, завданням якого є створення банку тестових завдань на основі тестів, розроблених кафедрами з усіх дисциплін, відповідно до модулів, розробка комп’ютерних програм автоматичного формування тестових питань та комп’ютерної перевірки. Розроблені положення про проведення тестового іспиту, критерії оцінювання з дисциплін, які відображені в “Методичних рекомендаціях для викладачів щодо організації навчального процесу в ТДМУ”.

5. Впровадження комп'ютерних технологій. Входження у світовий медичний освітній простір вимагає впровадження в навчальний процес сучасних інформаційних технологій. За сприяння і участю колективів і кафедр розроблені і розміщені на сайті на допомогу студенту робочі програми, методичні вказівки, розклади занять, графіки чергувань викладачів по кафедрах; набори слайдів до лекцій; матеріали до практичних занять; відеоматеріали по методиці обстеження хворих, окремі операції та їх етапи; презентації лекцій; база контролю знань із розсиланням центром тестування оцінок семестрових тестових іспитів; база ліній практичних навичок із результатами їх складання; база складання практично-орієнтованого іспиту ОСКI.

Ha Web-порталі створено електронну бібліотеку джерел навчальної мультимедійної інформації.

6. Впровадження віртуальних комп'ютерних програм. Для покращення якості засвоєння практичних навичок колективами кафедр розроблені віртуальні тренінгові програми з підтримкою 3D та мультимедіа.

7. Запровадження системи дистанційної освіти “Moodl”. Ця система функціонувала із 2006 року. Для поточної тестової самооцінки кафедрами був створений банк питань із тестами та ситуаційними задачами.

8. Написання підручників та посібників із хірургічних дисциплін, створення атласів, методичних посібників тощо.

3 участю циклового методкому розроблена програма створення сучасних підручників і атласів 3 дисципліни, які б відповідали наскрізній програмі вивчення предмета.

На всіх кафедрах хірургічного профілю були створені підручники, які отримали загальнодержавне визнання, а на кафедрі загальної хірургії комплексний підручник з хірургії, який отримав Державну премію України.

Набутий досвід ліг в основу розроблених національних навчальних програм, які пройшли широке обговорення в колективах хірургічних кафедр та цикловою методичною комісією і були рекомендовані до впровадження.

Для покращення навчального процесу за рекомендацією методкому на кафедрах створені мінібібліотеки з дисципліни, комп’ютерні, читальні, тренажерні та фантомні зали.

На закінчення підкреслимо, що циклова методична комісія 3 хірургічних дисциплін $є$ однією 3 ланок цілісної системи організації навчального процесу в медичному вищому навчальному закладі.

Висновки. 1. Циклова методична комісія з хірургічних дисциплін є важливим комплексним органом організації і координації навчального процесу у вищому навчальному закладі.

2. Комісія є однією з ланок реалізації навчального процесу, запровадження новітніх освітніх технологій, форм і методів інтерактивного навчання, удосконалення педагогічної майстерності науковопедагогічних працівників вищого навчального закладу. 


\section{Список літератури}

1. Концепція розвитку Тернопільського державного медичного університету імені I. Я. Горбачевського (інтеграція у світовий медичний освітній простір). Тернопіль : ТДМУ, 2006. - 50 с.

2. Ковальчук Л. Я. Впровадження новітніх методик і систем навчального процесу в Тернопільському державному медичному університеті імені I. Я. Горбачевського / Л. Я. Ковальчук // Медична освіта. - 2009. № 2. - С. 10-14.

3. Ковальчук Л. Я. Новітні шляхи вдосконалення підготовки фахівців у Тернопільському державному медичному університеті імені І. Я. Горбачевського / Л. Я. Ковальчук // Медична освіта. - 2010. - № 2. С. 27-30.

4. Впровадження об’єктивного структурованого клінічного іспиту (OCKI) в Тернопільському державному медичному університеті імені І. Я. Горбачевського / Л. Я. Ковальчук, І. Р. Мисула, І. Є. Сахарова, О. Є. Федорців // Медична освіта. - 2008. - № 2. - С. 43-44.

5. Семестрові комплексні тестові іспити - надійний критерій оцінки знань студентів / I. Р. Мисула,
В. П. Марценюк, К. О. Пашко, О. О. Стаханська // Медична освіта. - 2010. - № 1. - С. 16-37.

6. Горшунова Н. К. Інноваційні технології в підготовці лікаря в системі безперервної професійної освіти / Н. К. Горшунова // Фундаментальні дослідження. - 2009. № 2. - С. 87-88.

7. Закон України про вищу освіту : за станом на 1 лип. 2014 p. № 1556-VII // Відомості Верховної Ради України. 2014. - Т. 2004, № 37-38.

8. Компетентнісний підхід в освіті: теоретичні засади і практика реалізації : матеріали методол. семінару (Київ, 3 квіт. 2014 р.) / Нац. акад. пед. наук України; редкол.: В. Г. Кремень, В. І. Луговий, О. І. Ляшенко та ін. - К. : Ін-т обдарованої дитини НАПН України, 2014. - 370 с.

9. Опар Н. В. Особливості нормативно-правового забезпечення якості вищої освіти в Україні в умовах євроінтеграції / Н. В. Опар. - Режим доступу : httl:// el-zbirn-du.at.ua/2015_1/22.pdf.

10. Фіцула М. М. Педагогіка вищої школи / М. М. Фіцула. - К. : Академвидав, 2006. - С. 148-159.

ispyty - nadiinyi kryterii otsinky znan studentiv [Semester exams complex tests - reliable criterion for assessing students' knowledge]. Medychna osvita - Medical Education, 1, 16-37 [in Ukrainian].

6. Horshunova, N.K. (2009). Innovatsiini tekhnolohii v pidhotovtsi likaria v systemi bezperervnoi profesiynoi osvity [Innovative technologies in medical training in the system of lifelong professional education]. Fundamentalni doslidzhennia - Fundamental Studies, 2, 87-88 [in Ukrainian].

7. (2014). Zakon Ukrainy pro vyshchu osvitu: stanom na 1 lyp. 2014 r. № 1556-VII [Higher Education Act of Ukraine: as of July 1, 2014, № 1556-VII]. Vidomosti Verkhovnoyi Rady Ukrayiny - Verkhovna Rada of Ukraine Bulletin, 37-38 [in Ukrainian].

8. Kremen, V.H., Luhovyi, V.I., \& Liashenko, O.I. (Eds). (2014). Kompetentnisnyy pidkhid v osviti: teoretychni zasady i praktyka realizatsiyi [Competency approach in education: theoretical principles and practice of implementation]. K.: In-t obdarovanoi dytyny NAPN Ukrainy [in Ukrainian].

9. Opar, N.V. Osoblyvosti normatyvno-pravovoho zabezpechennia yakosti vyshchoi osvity v Ukraini v umovakh yevrointehratsii [Features of normative and legal maintenance of higher education quality in Ukraine in terms of European integration]. Retrieved from httl://el-zbirn-du. at.ua/2015_1/22.pdf [in Ukrainian].

10. Fitsula, M.M. (2006). Pedahohika vyshchoi shkoly [Pedagogy of High School]. K.: Akademvydav [in Ukrainian].
5. Mysula, I.R., Martseniuk, V.P., Pashko, K.O., \& Stakhanska, O.O. (2010). Semestrovi kompleksni testovi 